\title{
Pengaruh Jarak terhadap Efektivitas Komunikasi Antarpribadi (Studi Pada Mahasiswa Komunikasi Penyiaran Islam FDIK UIN IB)
}

\author{
Riza Nurfitri ${ }^{1}$, Neni Efrita ${ }^{2}$, Lidya Arman ${ }^{3}$, Prima Kurniati Hamzah ${ }^{3}$ \\ Universitas Islam Negeri Imam Bonjol \\ ${ }^{1}$ Email : rizanft07@gmail.com \\ ${ }^{2}$ Email : neniefrita@gmail.com \\ ${ }^{3}$ Email : lidyaarman4@gmail.com \\ ${ }^{4}$ Email : primakurniati@uinib.com
}

\begin{abstract}
Relationships between children and parents are so familiar or often communicate face to face because they live in one house. When far away the closeness of parents and children is still maintained as if they lived in one house or not. Basically, parents and children must want to communicate even if they are just asking to let go of homesickness. The purpose of this study is to find out and explain the effect of openness on long distance relationships, to determine the effect of empathy for long distance relationships, and to determine the effect of support for long distance relationships. This study uses quantitative research methods. Data collection techniques used were questionnaires. The questionnaire used has passed the validity test. Questionnaires were distributed to 42 respondents selected from 168 populations using random sampling techniques. The data obtained is processed using the SPSS data processing program. The results obtained were analyzed using descriptive analysis techniques. The results that can be taken from this study are: (1) aspects of selfopenness to long distance relationships are normal that self-disclosure does not have a significant relationship to long-distance relationships. (2) the aspect of empathy for long distance relationships is normal but the results of empathy are not related to long distance relationships. (3) aspects of support for long distance relationships are normal and support does not affect long distance relationships.
\end{abstract}

Keyword : distance; effectiveness; communication; personal

\begin{abstract}
ABSTRAK
Hubungan antara anak dengan orangtua begitu akrab atau sering berkomunikasi tatap muka karena tinggal dalam satu rumah. Saat berjauhan kedekatan orangtua dan anak masih tetap terjaga seperti mereka tinggal satu rumah atau tidak. Pada dasarnya orangtua dan anak pasti ingin berkomunikasi walaupun hanya sekedar menanyakan kabar untuk melepas rindu. Tujuan penelitian ini yaitu untuk mengetahui dan
\end{abstract}


menjelaskan pengaruh keterbukaan terhadap hubungan jarak jauh, untuk mengetahui pengaruh rasa empati terhadap hubungan jarak jauh, serta untuk mengetahui pengaruh dukungan terhadap hubungan jarak jauh. Penelitian ini menggunakan metode penelitian kuantitatif. Teknik pengumpulan data yang digunakan ialah angket. Angket yang digunakan telah melalui uji validitas. Angket disebarkan pada 42 orang responden yang dipilih dari 168 populasi dengan menggunakan teknik sampel acak. Data yang didapat diolah menggunakan program pengolahan data SPSS. Hasil yang diperoleh dianalisis dengan menggunakan teknik deskriptif analisis. Hasil yang dapat diambil dari penelitian ini adalah: (1) aspek keterbukaan diri terhadap hubungan jarak jauh bernilai normal bahwa keterbukaan diri tidak memiliki hubungan yang signifikan terhadap hubungan jarak jauh. (2) aspek empati terhadap hubungan jarak jauh bernilai normal namun hasil empati tidak berhubungan dengan hubungan jarak jauh. (3) aspek dukungan terhadap hubungan jarak jauh bernilai normal dan dukungan tidak berpengaruh terhadap hubungan jarak jauh.

Kata Kunci : jarak; efektivitas komunikasi; mahasiswa; komunikasi

\section{PENDAHULUAN}

Komunikasi adalah hubungan kontak antar manusia, baik individu maupun kelompok. Dalam kehidupan sehari-hari disadari atau tidak komunikasi adalah bagian dari kehidupan manusia. Terjadinya komunikasi adalah sebagai konsekuensi hubungan sosial (Social relation). Masyarakat paling sedikit terdiri dari dua orang yang saling berhubungan satu sama lain yang karena berhubungan menimbulkan interaksi sosial (social interaction).

Menurut Kumar (2007), efektivitas komunikasi antarpribadi mempunyai lima ciri sebagai berikut keterbukaan (openess), yaitu kemauan menanggapi dengan senang hati informasi yang diterima di dalam menghadapi hubungan antar pribadi, Empati (empathy), yaitu merasakan apa yang dirasakan orang lain, dukungan (supportiveness), yaitu situasi yang terbuka untuk mendukung komunikasi berlangsung efektif, rasa positif (positiveness), dimana seseorang harus memiliki perasaan positif terhadap dirinya, mendorong orang lain lebih aktif berpartisipasi, dan menciptakan situasi komunikasi kondusif untuk interaksi yang efektif dan kesetaraan (equality), yaitu pengakuan secara diam-diam bahwa kedua belah pihak menghargai, berguna, dan mempunyai sesuatu yang penting untuk disumbangkan.

Perkembangan zaman yang terus berkembang akan mempengaruhi setiap keluarga untuk membentuk anggota keluarga menjadi individu yang cerdas. Karena itu, banyak orangtua yang ingin memberikan pendidikan yang terbaik untuk anak mereka. Para orangtua juga rela terpisah jauh dengan anak mereka demi masa depan dan cita-cita yang akan dicapai oleh anak yang mereka cintai. Hal ini karena menurut para orangtua banyak sekolah dan universitas memiliki 
kualitas yang baik berada di luar kota dari tempat tinggal mereka. Sehingga para orangtua tetap memberikan motivasi agar anaknya tetap mendapat pendidikan yang terbaik walau harus tinggal terpisah dengan orangtua.

Walaupun begitu banyak alat komunikasi yang dapat digunakan untuk menjalin komunikasi antara anak dan orangtua yang tinggal terpisah, tidak dapat dipungkiri bahwa hubungan yang mereka jalani tidak selamanya berjalan dengan baik. Ada beberapa masalah yang dihadapi oleh para mahasiswa. Misalnya, masalah psikologis dan masalah ekonomi yang dihadapi oleh mahasiswa yang tinggal terpisah dengan orang tuanya. Masalah psikologis seperti, menahan rasa rindu kepada orangtua dan anggota keluarga lainnya dan harus terbiasa melakukan semua aktivitas sendiri dan tanpa bantuan dari orangtua.

Permasalahan komunikasi jarak jauh antara orang tua dengan anak ini menarik untuk diteliti karena pada umumnya anak dengan orang tua berhubungan dekat atau sering berkomunikasi tatap muka karena tinggal dalam satu rumah. Orang tua dengan anak memiliki kedekatan emosional satu sama lain dan kedekatan batin karena ikatan orang tua dengan anak, hal itulah yang menjadikan hubungan komunikasi antara orang tua dengan anak menjadi dekat. Seorang anak pasti ingin berkomunikasi dengan ibu atau ayahnya walaupun sekedar basa-basi atau curhat mengenaiperkuliahannya. Begitupun orang tua pasti ingin berkomunikasi dengan anaknya walaupun hanya mengingatkan untuk makan saja. Tetapi lain halnya dengan orang tua dan anak yang tidak tinggal serumah atau tinggal berjauhan karena perbedaan jarak dan tempat.

\section{METODE PENELITIAN}

Model penelitian ini menggunakan pendekatan kuantitatif. Populasi dari penelitian ini ialah Mahasiswa Komunikasi Penyiaran Islam angkatan 2015-2016 yang aktif, yang jauh dari orangtuanya. Sampel penelitian berjumlah jumlah 42 mahasiswa. Penetapan sampel yang digunakan dalam menggunakan jenis metode random sampling (sampel acak).

Instrumen penelitian yang digunakan dalam penelitian ini ialah angket atau kuesioner yang telah divalidasi. Data diolah menggunakan SPSS versi 40. Uji statistik yang digunakan adalah korelasi dan regresi linear.

\section{HASIL DAN PEMBAHASAN}

1. Hubungan antar variabel independen dengan dependen

\begin{tabular}{lll}
\hline No & Variabel & R Square \\
\hline 1 & $\begin{array}{l}\text { Motif Keterbukaan } \\
\text { diri }\end{array}$ & 1 \\
\hline 2 & Motif Empati & 0,789 \\
\hline 3 & Motif Dukungan & 0,646 \\
\hline 4 & $\begin{array}{l}\text { Motif Hubungan } \\
\text { Jarak Jauh }\end{array}$ & 0,062 \\
\hline
\end{tabular}


Tabel 1. Hubungan masing- masing Variabel independen dengan variable dependen

\section{a) Keterbukaan Diri}

Jika keterbukaan diri (X1) dihubungkan dengan hubungan jarak jauh, maka diperoleh angka 0,062. Dilihat dari tabel interval koefisien, hal ini berarti, korelasi antara keterbukaan diri (variabel X1) dengan hubungan jarak jauh sangat rendah. Dari hasil nilai korelasi keterbukaan diri diperoleh nilai positif, tetapi nilai menunjukkan 0,699 yang mana Sig. $>$ 0,05 ini menunjukkan adanya korelasi yang tidak signifikan. Sehingga jika di dalam hubungan jarak jauh terjadi keterbukaan diri maka efektivitas komunikasi antar pribadi menurun.

\section{b) Empati}

Jika empati (X2) dihubungkan dengan hubungan jarak jauh, maka diperoleh angka 0,120. Hal ini berarti, korelasi antara empati (variabel X2) dengan hubungan jarak jauh sangat rendah di lihat berdasarkan tabel interval koefisien. Dari hasil nilai korelasi empati diperoleh nilai yang sig sebesar 0,451 yang bernilai positif, meskipun begitu nilai sig. $>0,05$ yang mana menunjukkan tidak adanya korelasi yang signifikan terhadap hubungan jarak jauh. Sehingga jika di dalam hubungan jarak jauh terjadi empati maka efektivitas komunikasi antar pribadi menurun.

c) Dukungan
Jika dukungan (X3) dihubungkan dengan hubungan jarak jauh, maka diperoleh angka 0,170. Hal ini berarti, korelasi antara dukungan (variabel X3) dengan hubungan jarak jauh sangat rendah. Dari hasil nilai korelasi dukungan diperoleh nilai positif sebesar 0,283 yang mana nilai sig. > 0,05, ini menunjukkan tidak adanya korelasi yang signifikan terhadap hubungan jarak jauh. Sehingga jika didalam hubungan jarak jauh terdapat dukungan maka efektivitas komunikasi antar pribadi tetap menurun.

\section{Variabel dominan yang mempengaruhi kepuasaan}

\begin{tabular}{|c|c|c|c|c|}
\hline $\begin{array}{l}\mathbf{N} \\
\mathbf{0}\end{array}$ & Variabel & $\begin{array}{l}\text { B } \\
\text { Beta }\end{array}$ & $\begin{array}{l}t \\
\text { Hitun } \\
g\end{array}$ & $\begin{array}{l}P \\
\text { Valu } \\
e \\
\end{array}$ \\
\hline 1 & $\begin{array}{l}\text { Motif } \\
\text { Keterbukaan } \\
\text { diri }\end{array}$ & - & & \\
\hline 2 & Motif Empati & $\begin{array}{l}0,16 \\
6\end{array}$ & $\begin{array}{l}- \\
0,602\end{array}$ & $\begin{array}{l}0,55 \\
1 \\
\end{array}$ \\
\hline 3 & $\begin{array}{l}\text { Motif } \\
\text { Dukungan }\end{array}$ & $\begin{array}{l}0,12 \\
7\end{array}$ & 0,463 & $\begin{array}{l}0,64 \\
6 \\
\end{array}$ \\
\hline 4 & $\begin{array}{l}\text { Motif } \\
\text { Hubungan } \\
\text { Jarak Jauh }\end{array}$ & $\begin{array}{l}0,19 \\
5\end{array}$ & 0,903 & $\begin{array}{l}0,37 \\
2\end{array}$ \\
\hline
\end{tabular}

Tabel 2. Hubungan masing- masing Variabel independen dengan variable dependen

Berdasarkan tabel di atas, diperoleh nilai signifikansi keterbukaan diri (X1) sebesar 0,551 serta nilai $\mathrm{T}$ hitung sebesar $-0,602$. Artinya nilai signifikansi variabel 
X1 lebih besar dari pada 0,05. Sedangkan nilai $\mathrm{T}$ hitung variabel $\mathrm{X} 1$ lebih kecil jikadibandingkan dengan nilai $\mathrm{T}$ tabel 2,024. Berdasarkan hasil tersebut dapat disimpulkan bahwa keterbukaan diri tidak berpengaruh signifikan terhadap hubungan jarak jauh, sehingga Ho diterima dan Ha ditolak.

Sedangkan pada empati, diperoleh nilai signifikansi sebesar 0,646 serta nilai $\mathrm{T}$ hitung sebesar 0,463. Artinya nilai signifikansi variabel X2 lebih besar dari pada 0,05 . Sedangkan nilai $\mathrm{T}$ hitung variabel X1 lebih kecil jika dibandingakan dengan nilai $\mathrm{T}$ tabel 2,024. Berdasarkan hasil tersebut dapat disimpulkan bahwa empati tidak berpengaruh signifikan terhadap hubungan jarak jauh, sehingga Ho diterima dan Ha ditolak.

Serta pada dukungan, diperoleh nilai signifikansi sebesar 0,372 serta nilai $\mathrm{T}$ hitung sebesar 0,903. Artinya nilai signifikansi variabel X3 lebih besar dari pada 0,05 . Sedangkan nilai $\mathrm{T}$ hitung variabel X3 lebih kecil jika dibandingakan dengan nilai $\mathrm{T}$ tabel 2,024. Berdasarkan hasil tersebut dapat disimpulkan bahwa dukungan tidak berpengaruh signifikan terhadap hubungan jarak jauh, sehingga Ho diterima dan Ha ditolak.

\section{KESIMPULAN}

Dari hasil nilai korelasi keterbukaan diri diperoleh nilai positif tetapi nilai sig. >0,05, ini menunjukkan tidak adanya korelasi yang signifikan. Pada analisis uji T dan uji F, di mana keterbukaan diri tidak berpengaruh signifikan terhadap hubungan jarak jauh.

Dilihat dari tabel interval koefisien, hal ini berarti korelasi antara empati (variabel X2) dengan hubungan jarak jauh sangat rendah. Dari hasil nilai korelasi empati diperoleh nilai sig.

$>$ 0,05 yang bernilai positif, ini menunjukkan tidak adanya korelasi yang signifikan terhadap hubungan jarak jauh. Sehingga jika di dalam hubungan jarak jauh terjadi empati maka efektivitas komunikasi antarpribadi menurun. Dilihat dari uji F bahwa tidak terdapat di mana empati juga tidak memiliki hubungan yang signifikan terhadap hubungan jarak jauh.

Pada analisis uji korelasi pearson di jelaskan bahwa dukungan (X3) dihubungkan dengan hubungan jarak jauh, diperoleh angka 0,170 yang mana memiliki hubungan yang rendah dilihat dari tabel interval koefisien. Hal ini berarti, korelasi antara dukungan (variabel X3) dengan hubungan jarak jauh tidak adanya korelasi. Dari hasil nilai korelasi dukungan diperoleh nilai positif yang menunjukkan $>0,05$, ini menunjukkan tidak adanya korelasi yang signifikan.

\section{DAFTAR KEPUSTAKAAN}


Ahmadi, Abu, Psikologi Sosial, Rineka Cipta, Jakarta, 2007.

Arikunto, Suharsimi, Dkk., Penelitian Tindakan Kelas, Jakarta : Bumi Aksara,

2008.

Budyatna, Muhammad, Leila Mona Ganiem. Teori Komunikasi Antarpribadi,

Jakarta: Kencana Prenada Media Group, 2011.

Cangara, Hafied. Pengantar Ilmu Komunikasi, Edisi Kedua, Jakarta: PT.

RajaGrafindo Persada, 2012.

Danim, Sudarwan.

Motivasi

Kepemimpinan \& Efektivitas

Kelompok, Jakarta

Rineka Cipta, 2012.

Djamarah, Syaiful Bahri. Pola Asuh Orang

Tua dan Komunikasi dalam

Keluarga,

Upaya Membangun Citra Membentuk

Pribadi Anak, Edisi Revisi, Jakarta:

PT. Rineka Cipta, 2014.

Effendy, Onong Uchjana. Ilmu Komunikasi

Teori dan Praktek, Bandung: PT.

RemajaRosdakarya, 2009.

IAIN Imam Bonjol Padang, Pedoman Penulisan Karya Ilmiah (Tugas akhir,

Skripsi, Tesis \& Disertasi). Padang, 2014.

Kriyantono. Rahmat. Teknik Praktis Riset Komunikasi, Jakarta: Kencana, 2009.

Maulana. Herdiyan, dkk. Psikologi Komunikasi dan Persuasi, Jakarta: Akademia
Permata, 2013.

Prasetyo, Bambang dan Lina Miftahul Jannah. Metode Penelitian Kuantitatif

Teori dan Aplikasi, Jakarta: Rajawali Pers, 2014.

Rusli, Meiliarni, dkk, Ilmu Komunikasi Kajian komunikasi Antarpribadi, Jakarta:

The Minangkabau Foundation, 2002. Umar, Husein. Metode Penelitian Untuk Skripsi dan Tesis Bisnis, Jakarta: PT RajaGrafindo Persada, 2007.

Widodo, Metodologi Penelitian Populer \& Praktis, Jakarta : PT. RajaGrafindo Persada, 2017. 